\title{
Didaktiska reflektioner om judendom, stereotyper och tankefigurer
}

\author{
HÅKAn Bengtsson
}

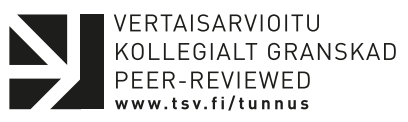

DOI: https://doi.org/10.30752/nj.89966

\begin{abstract}
AвstRACT $•$ This article addresses the issue of teaching Judaism for students in the teacher-training programme and those training to become clergy in a Swedish milieu. A major challenge in the secular post-Protestant setting is to pinpoint and challenge the negative presuppositions of Judaism as a religion of legalism, whereas the student's own assumption is that she or he is neutral. Even if the older paradigms of anti-Jewish stereotypes are somewhat distant, there are further patterns of thought which depict Judaism as a 'strange' and 'legalistic' religion. Students in the teacher-training programme for teaching religion in schools can in class react negatively to concepts like kosher slaughter, circumcision and the Shabbat lift. Even if the explanatory motives vary, there is nonetheless a tendency common to ordination students, relating to a Protestant notion of the Jewish Torah, commonly rendered as 'Law' or 'legalism'. This notion of 'the Law' as a means of self-redemption can, it is argued in the article, be discerned specially among clergy students reading Pauline texts and theology. This analysis shows that both teacher-training and textbooks need to be updated in accordance with modern research in order to refute older anti-Jewish patterns of thought. As for the challenge posed by the simplistic labelling of both Judaism and Islam as religions of law, the implementation of the teaching guidelines concerning everyday 'lived religion' enables and allows the teacher to better disclose Judaism, Christianity and Islam as piously organised living faiths rather than as being ruled by legalistic principles.
\end{abstract}

Att undervisa om religion i ett sekulariserat samhälle ställer läraren inför en rad didaktiska utmaningar, men erbjuder samtidigt möjligheter. Medvetenheten om problemen med att framställa judendomen på de negativa sätt som skett under historien, är väl representerad bland dagens teologer och religionslärare i skolan. Tillika med uppmärksammandet av religionens vardagsdimensioner som mat, kläder och seder, minskar risken att exotisera de religiösa utövarna. Å andra sidan ifrågasätts med jämna mellanrum rätten till omskärelse som en religiös identitetsmarkör. Det finns i den samtida svenska debatten en outsagd måttstock med vilken religiösa uttryck mäts. Denna måttstock förutsätter att uttryck för religiös identitet primärt hör hemma i en sfär av åsikter eller emotionella hållningar och inte som praxis. Kritiken har drabbat islam hårdare än judendom, men som lärare på högskolenivå har jag noterat att en del seglivade negativa förförståelser om judisk tradition lever kvar.

I denna artikel vill jag analysera och diskutera olika reaktioner på judendom och judiska seder som jag har mött då jag undervisat på svenska universitet och högskolor. Min erfarenhet sträcker sig från utbildning av blivande präster till blivande lärare, inom ramen för kurser i bibelvetenskap och i "världsreligionerna" där judendomen ingår. Även i min forskning har jag arbetat med 
stereotypa framställningar av judendom i svensk bibelforskning (Bengtsson 2006).

En generell observation är att studenters uppfattningar om judendom skiljer sig mellan just prästutbildning och lärarutbildning. Jag vill karaktärisera lärarstudenters inställning till judendom som öppen där dock en del judiska seder uppfattas negativt, medan präststuderande har en mer utpräglat negativ förförståelse av vad man förstår vara den judiska lagen. Något förenklat kan man säga att dessa förförståelser av judendomen varierar beroende på studenternas förkunskaper. Lärarprogrammet är ett sammanhang där studenternas uppfattning om religion till större delen har präglats av grundskola och gymnasium, medan de flesta präst- eller pastorsstuderande dessutom socialiserats in $\mathrm{i}$ olika luthersk-protestantiska samfund. Analysen som framläggs här baseras inte på empiriska data utan på observationer och reflektioner som jag gjort under två decenniers undervisning. Analysen har stöd i aktuell religionsdidaktisk forskning och med hjälp av den tecknas bilden av hur debatt och forskning har börjat förändra bilden av judendomen till det bättre.

Mina undervisningserfarenheter bestäms av att jag främst arbetat i ett svenskt sammanhang. Då jag under ett antal år arbetade med religionsmöten, dialog och judiskkristna relationer i Jerusalem mötte jag andra förhållningssätt till religion än de svenska. Det blev tydligt för mig hur religionsförståelsen i Sverige är präglad av både protestantiska ideal och upplysningsideal, nämligen att religion har mer med insidan av en människa att göra, än med utsidan. I Jerusalems plurala religionsmiljö anknyter man religion främst till identitet och påtagliga levnadsmönster som klädsel, mat och dagliga böner. Religiös praktik ingår i vardagen på ett helt annat sätt

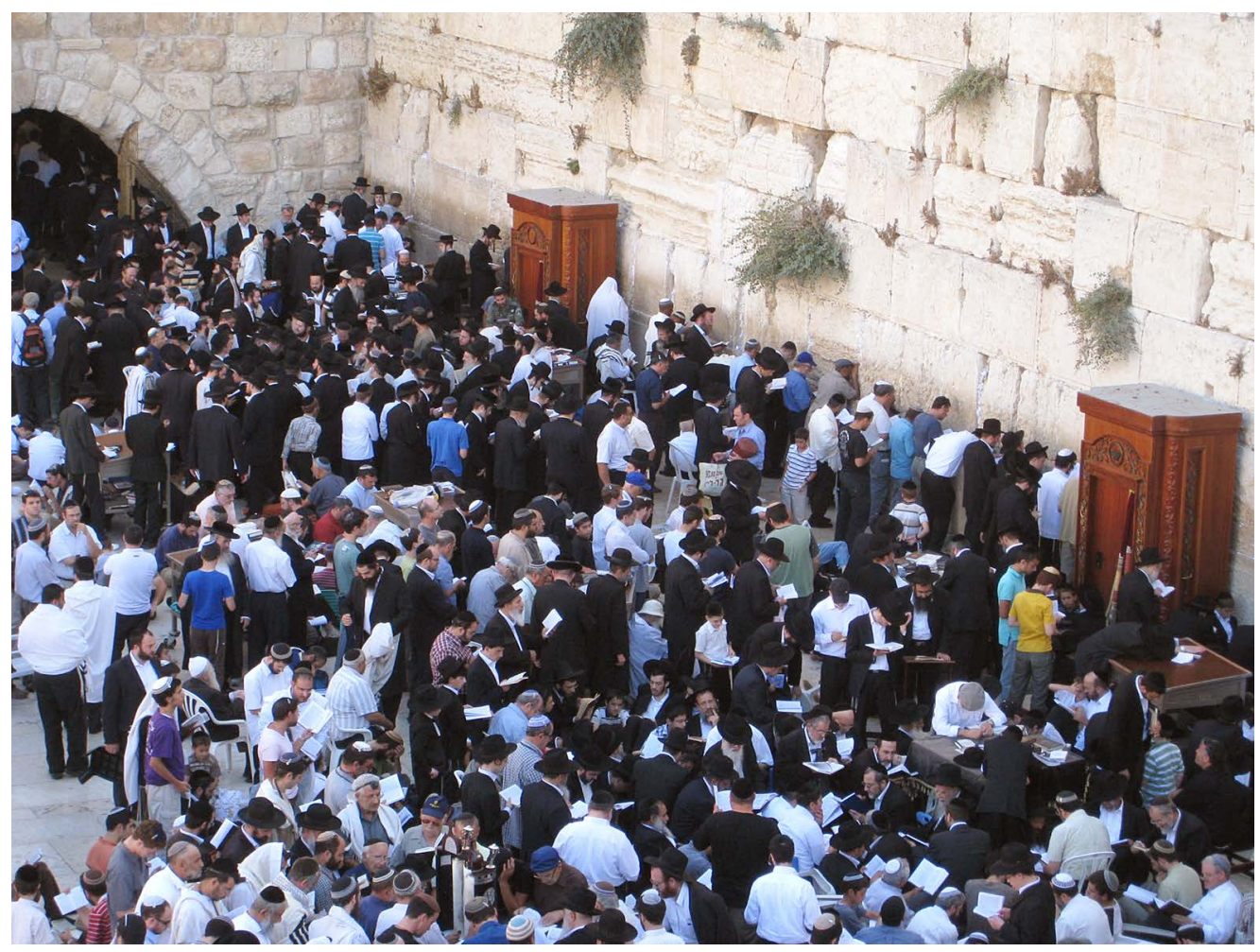

Bön vid Västra muren i Jerusalem. Foto: Ulf Petersson. 
än i Sverige. Tyvärr uppfattas dock delar av religiös vardagspraktik som hotande och problematisk i Sverige. Det religiösa landskapet i Sverige har förändrats vilket inneburit att frågan om religiös praxis har kommit i fokus, samtidigt som åsikterna om religion polariserats. Detta beror delvis på politiska agendor, men också på oförståelse och okunskap om vad olika religiösa seder och traditioner betyder och innebär.

\section{Religion och förändring i Sverige}

Den svenska modellen med skolämnet religionskunskap har länge setts som en god utgångspunkt för att religiösa traditioner och deras utövare ska förstås på ett nyanserat och balanserat sätt (Berglund 2013: I76). Läroplanernas målsättningar är tydliga: kunskaper om religion och livsåskådning ska öka respekt och förståelse, samt motverka fördomar. Här betonas inte enbart kunskaper om religion, utan även förståelse för hur religion uttrycks i samhället. Religionsdidaktisk forskning visar dock att denna målsättning riskerar att gå förlorad då religionsundervisning i en del fall kan alienera eleverna från en mångsidig förståelse av religion (Kittelman Flensner 2015).

I den nyligen utkomna studien Sveriges religiösa landskap, beskriver Erika Willander den svenska religiösa kartan i termer av både förändring och konstans. Kortfattat kan sägas att Willander inte ser någon ökning av vare sig religiös aktivitet eller ökad pluralism i Sverige under det senaste decenniet. En i sammanhanget viktig iakttagelse som Erika Willander gör är att något över hälften av Sveriges befolkning saknar personlig erfarenhet av religionsutövning: "När de flesta i Sverige talar om religionsutövning talar de därför om någon annans religionsutövning" (Willander 201 9: 82). Om en personlig erfarenhet av religion saknas hämtas information från andrahandskällor. Här föreligger risken att olika polariserade uppfattningar om religion överförs okritiskt eller tas för givna.

Willander ställer följdriktigt frågan på vilka sätt kunskap om religion förmedlas, speciellt de olika samfunden emellan (2019: 82). I denna artikel arbetar jag, som sagt, med två generella kategorier. Den ena består av lärarstudenter som generellt sett har liten egen erfarenhet av religionsutövning eller en uttalad religionstillhörighet. Den andra kategorin består av präststudenterna som ofta har ett personligt engagemang i kristna samfund och en övertygelse som motiverar dem att $\mathrm{i}$ framtiden arbeta inom dessa sammanhang. Med risk för att generalisera vill jag hålla fast vid denna utgångspunkt eftersom frågan om varifrån studenterna har sina kunskaper och erfarenheter spelar roll för analysen.

\section{Judendomen i läroböcker}

Hur har judendomen framställts i svenska läroböcker? Under de senare decennierna har denna fråga inte genererat samma intensiva diskussion som bilderna av islam i svenska läroböcker. Frågan är dock inte ny. I början av I980-talet initierade The International Council of Christians and Jews en undersökning där frågan ställdes hur judendomen framställdes i europeiska och nordamerikanska läroböcker. Från svenskt håll påpekade Gunnel Borgegård ett antal problem med både faktafel och generaliserande tendenser i skolläroböcker från I 970- och 80-talen (Borgegård I986).

Ett par mer metodologiskt drivna studier har gjorts kring framställningen av judendomen i svenska läroböcker (Löwengart 2004: 25). Stéphane Bruchfelds studie Öga för öga, tand för tand publicerades I996. Undersökningen var historiedidaktisk och hans bedömning av skildringen av judisk historia i svenska läromedel var att 
den var "knapphändig och ofta distanserad" (Bruchfeld r996: 6). En liknande inriktning på historieböcker, fokuserad på antisemitism och Förintelsen, hade också Mia Löwengarts undersökning. Hennes slutsats var att ingen av de undersökta läroböckerna hade "på ett sakligt och tillräckligt utförligt sätt lyckats behandla antisemitismens historia och Förintelsens historia i Europa eller hur Förintelsen påverkade Sverige..." (Löwengart 2004: 46).

Om de ovan redovisade undersökningarna främst underströk brister i läroböckerna, ger Leif Carlssons studie Det förkastade judefolket (2013) en något annorlunda bild av judendomen i svenska läromedel. Carlsson visar på hur en genomgående negativ, judendomskritik tendens kan påvisas i läroböcker från r 900-talets början till runt r960. Denna är då till stora delar styrd av en dogmatisk kristen syn på judendomen. De senare decenniernas läromedel speglar dock judendomen på ett positivare och rättvisare sätt, även om en ortodox luthersk värdering av judendomen som en förtjänstreligion dröjer kvar (Carlsson 201 3: г 86-г 87). Det är glädjande att på det viset konstatera att inga av de grova äldre antisemitiska stereotyperna finns kvar, även om judendomen presenteras utifrån protestantiska förutsättningar. Judendomen som en lagreligion är en seglivad föreställning i detta sammanhang (Illman r 986: 4).

\section{Stereotyper och tankefigurer}

Många av de problematiska skildringarna av judendomen i läroböcker benämns med termen stereotyp. Samtidigt är det uppenbart att föreställningar som "judendomen är en lagreligion" inte direkt kan betecknas som en stereotyp, om man jämför med de mer antisemitiskt präglade föreställningarna. I sin avhandling analyserar Lars M. Andersson karikatyrer av judar i svensk skämtpress. Ett bärande tema är förhållandet mellan stereotyper och antisemitism. För att kunna diskutera detta förhållande utgår jag, liksom Andersson, från Helen Feins mångsidiga definition av antisemitism, där en av poängerna är att den odlas i kultur och i ideologi (Andersson 2000: I7). Andersson framhåller just att stereotyper är kollektiva skapelser vilka odlas och understöds i olika grupperingar och kulturer (ibid. s. 84). Detta är en viktig slutsats som har relevans i undervisning och för skolsituationen. Stereotyper är också vanliga i antisemitiska diskurser där bland annat demoniseringen utmärker dem. Ursprunget för de vanligaste antijudiska stereotyperna är, inte förvånande, medeltida.

Vilka stereotyper om judar har varit vanliga i modern tid? Lars M. Andersson väljer fem för honom relevanta typer, vilka är hämtade från Helen Feins artikel "Dimensions of antisemitism" från I 987 (Andersson 2000: 85). Av dessa är "förrädaren" (urtypen är Judas Iskariot), "kapitalisten" eller "utsugaren" (Shakespeares Shylock) och "mördaren" (den demoniserade juden) de mest relevanta i mitt sammanhang. Till dem vill jag lägga "offret eller syndabocken" och "världskonspiratören" (från Sions vises protokoll). Syftet här är inte att renodla specifika stereotyper, utan snarare se vilka varianter av stereotyper som kan spela roll i debatter och diskussioner. Andersson påpekar att det är kombinationerna, ofta just det motsättningsfulla ("offretvärldskonspiratören"), som blir det effektfulla och bärande (ibid. s. 85).

Detta stämmer väl in på hur begreppet "stereotyp" växt fram och använts under I 900-talet. När Walter Lippmann I 922 lanserade begreppet stereotyp, menade han att dessa utgjorde grova förenklingar av olika grupper av människor. Själva beteckningen "typ" (av grekiskans typos) anspelar på sättningen av typerna vid mekanisk texttryckning. Uppsättningen av tecken är den samma 
och reproduktionen likaså (Pickering 200 I: 9). Lippmann betonade att stereotyper både fanns i kulturen och skapades av människor för att sortera och kategorisera i en komplex värld (Hinton 2000: I 3-I 5). En stereotyp är nödvändigtvis inte samma sak som en fördom. Man brukar dock idag framhålla att en stereotyp underförstår att en grupp av människor besitter en essentiell egenskap eller karaktär. Innehållet i andra kategoriseringar kan skifta, men en stereotyp är relativt oförändrad över tid. Stereotypernas relation till språk, historia, kultur och sociologiska processer är aspekter som betonas tydligare idag. Med andra ord diskuteras oftare stereotypernas meningsskapande funktion än deras möjliga ursprung (ibid. s. 28-29). En negativ stereotyp används alltså ofta i propagandasyfte för att framhålla vad man upplever som ett hot från en viss grupp.

På ett sätt är begreppet "stereotyp" ett trubbigt analysinstrument i sammanhanget. Få studenter kan identifiera de grova äldre ofta teologiskt grundade stereotyperna. De stereotyper som kan skymta fram i undervisningen finns representerade $i$ de samtida mediala diskussionerna om Förintelsen och om staten Israel. Här kan man känna igen idén om juden dels som "offret" eller "syndabocken" eller "juden som makthungrig". Som jag påpekat är dessa varandras motsatser, vilket gör dem användbara för olika grupper, i olika situationer.

Man kan alltså diskutera hur man ska definiera begreppet "stereotyp" i relation till fördomar eller problematiska tankefigurer. De två senare termerna kan täcka in lite vidare fält än stereotyper och det är just det senare begreppet "tankefigurer" som jag anser passar bättre när det gäller mer moderna teologiska föreställningar relaterade till judendomen. Jonathan D. Brumberg-Kraus diskuterar begreppet "troper" och vad han kallar "ideological figures" i relation till moderna judiska missförstånd om kristendom och Nya testamentet (Brumberg-Kraus I 997: I 22). Han analyserar tankefigurer som "Jesus var jude", "Paulus var goyish", det vill säga ickejudisk. Hans punkt "judar gör medan kristna tror" kommer närmast det jag vill diskutera, nämligen en föreställning som generaliserar, men inte direkt är knuten till någon av de grövre förmoderna stereotyperna. En sådan föreställning är skapad under mer moderna förutsättningar och överförs i sociala sammanhang där den hjälper till att förklara olika förhållanden, eller förstärker redan givna uppfattningar (ibid. s. I 22). Termen "tankefigurer" fångar lättare in problemkomplex med religion som både tro och handling, vilket jag nu kommer att diskutera i relation till den svenska skolan och aktuell debatt.

\section{Religionsämnet i svensk skola}

Jag återvänder nu till religionsämnet i den svenska skolan för att beskriva hur det utvecklats sedan I 970-talet. I I 969 års läroplan (Lgr 69) fick religionsämnet beteckningen "religionskunskap". Tidigare hade ämnet kallats "kristendomskunskap". Namnändringen till trots menar Sven Hartman (2000) att inriktningen i Lgr 69 inte var radikalt annorlunda än i den tidigare läroplanen från I 962. Kristendomskunskapen gav visserligen utrymmesmässiIgt företräde för kristendomen, men erbjöd också orientering om världsreligioner, samt något om religionskritiska strömningar. Här fanns också ett uttalat krav på objektivitet och saklighet i undervisningen. Den avgörande skillnaden i Lgr 69 var att lärarens urval av undervisningsmaterial blev friare och att man lade större vikt vid elevens egna livsfrågor (Hartman 2000: 219-220).

Denna svenska modell med religionskunskap som obligatoriskt skolämne är speciell i ett europeiskt perspektiv. Vanligare är det att 


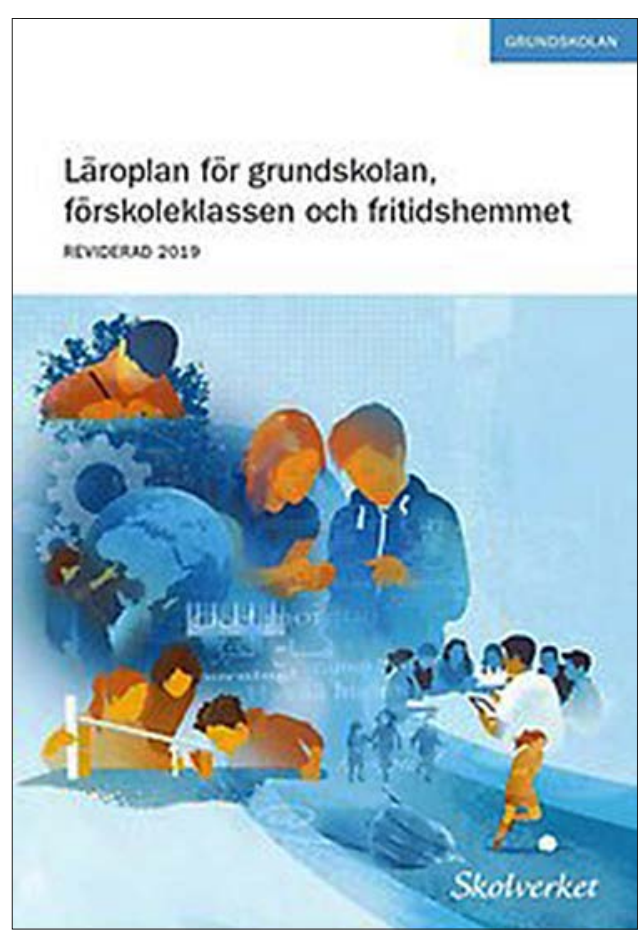

Omslaget på läroplan för grundskola med mera.

elever undervisas separat efter sina respektive religiösa tillhörigheter, till exempel i Belgien, Finland, Italien, Spanien, Tyskland och Österrike. Eleverna får då undervisning både i sin egen religiösa tradition och om andras. I relation till denna mer religionstillhörighetsbaserade modell uppfattas ofta religionskunskapsämnet i svenskt sammanhang som just neutralt och icke-konfessionellt (Kittelman Flensner 201 5:28).

I det svenska sammanhanget konstaterar Hartman vidare att kravet på objektivitet av många lärare upplevdes som svårtolkat och ledde inte sällan till en ängslighet för att överträda sina befogenheter. I de följande läroplanerna betonades vikten av att större utrymme gavs åt livsåskådningsfrågor och mer praxisrelaterad religionsutövning (Hartman 2008: 79-80). Beskrivet i didaktiska termer kan man blanda lärande om religion med lärande från elevens egna livsförståelser och existentiella tolkningar (Byrne 20I4: 8I).

Inte heller denna möjlighet tycktes förlösa ämnet från upplevelsen av objektivitetskravets kvävande grepp. Undervisande lärare upplevde att de kryssade mellan det livfulla engagemangets Karybdis och det faktatorra Skylla. Jon Magne Vestøl (20 I 5) påpekar att i ett mångreligiöst klassrum upplever många konfessionellt medvetna elever undervisningen som just stereotypiserande och förenklande av deras egen religion. I den sekulära andan riskerar religionsundervisningen enbart handla om materiella eller sociopolitiska förutsättningar. De märgfulla berättelserna och de emotionella dimensionerna går förlorade (Vestøl 20 I5: 10). Detta är också en erfarenhet som många svenska lärarstudenter kommunicerar. Religionsämnet upplevdes som faktabetonat och sterilt.

\section{Religion som något annorlunda och reaktionärt}

Än mer problematiska är några fall av religionsundervisning i svenska skolor som Karin Kittelman Flensner redovisar i sin avhandling Religious Education in Contemporary Pluralistic Sweden (20 I 5). Kittelman Flensner genomförde sin studie genom observerande deltagande i tre olika skolor, en nära en storstad, en annan i en landsbygdskommun och den tredje i en mellanstor svensk stad. Under två år följde hon I 3 lärares undervisning i ett tjugotal olika klasser (Kittelman Flensner 20I5: 92). Även om resultatet av Karin Kittelman Flensners forskning pekar på problem och brister i undervisningen, måste man fråga till vilken del slutsatserna är generaliserbara. Många lärare bedriver en kvalificerad undervisning i religion. Kittelman Flensners undersökning visar dock att objektivitetsidealet $\mathrm{i}$ sig inte garanterar en problemfri religionsundervisning. 
Kittelman Flensner kunde observera flera diskurser om religion i klassrummen. Den dominerande var den sekularistiska, i vilken religiösa utövare framställdes som antikverade, irrationella och till och med duperade. Det normala framstår som att vara ickereligiös eller ateist, medan religiositet är svårförenligt med modernitet och rationalitet (Löfstedt 201 8: 219).

Bland de andra diskurserna fanns också en slags svenskhetsdiskurs där en dikotomi mellan "vi" (de svenska, kristna traditionerna) och "dom" (de andra religionerna, speciellt islam) var utmärkande. I den tredje diskursen, kallad den spirituellt-andliga, var det betydligt mer okomplicerat. Här diskuterades livsåskådning och existentiella frågor (Kittelman Flensner 2015: 256). Kittelman Flensner påpekar följdriktigt att de två första diskurserna knappast lever upp till målsättningen med mångsidighet och objektivitet som läroplanen föreskriver.

Att framställa religion som något främmande bidrar naturligtvis inte till en ökad förståelse. Ett växande problem i det svenska sammanhanget är oförmågan att förstå och respektera religiösa traditioner där starka övertygelser och markerade handlingssätt spelar en central roll i den religiösa identiteten. Judendomen är en sådan tradition vilken i sina ortodoxa former betonar vikten av firandet av sabbaten, högtider, matprinciper och klädstil. Sådana identitetsmarkörer, vilka är mest påtagliga i ortodoxa sammanhang, riskerar att missförstås. Utövarna av religionen betraktas som avvikande och konstiga. I relation till judendom är dock inte den här sortens vantolkningar ett nytt fenomen. Som tidigare påpekats har den kristna traditionen, speciellt den lutherska, ofta framställt judendomen som ett system av paragraflydnad (Carlsson 2013: I 47-I48).

\section{Islam och judendom som måltavlor för religionskritik}

I samtiden är det snarare islam, vilken jämfört med judendomen är ny som religiös tradition i Sverige, som är måltavlan för kritik angående fasta principer och främmande livsstil. I Mattias Martinsons analys (2017) av religionsdebatten i Sverige under 2000-talet konstateras att den aktuella debatten är polariserad. I debatten framställs svensk kristenhet som både politiserad och i förfall, medan islam framstår som principfast och dessutom på frammarsch (Martinson 20I7: 9). Den högerkonservativa polemiken har inriktat sig på islam, vilken är en religiös tradition där man något generaliserat kan säga att övertygelsen spelar lika stor roll som livsstilen. Det vill säga, övertygelsen levs ut $\mathrm{i}$ handlingsmönster (Berglund 2018: 278-280).

Frågan är om svensk judendom och judisk kultur delvis hamnat i skuggan av denna debatt, därför att den på samma sätt som svensk protestantism ofta betraktas som en religion införlivad i svensk kultur. Undantaget gäller den tilltagande antisemitismen i Europa, vilken ofta felaktigt drar likhetstecken mellan europeiska judar och staten Israels politik (Bunzl 2007: 7). Diskussioner om Israel-Palestinakonflikten blir ofta polemiska och såriga, vilket föranleder lärare att hålla den utanför klassrummet (Larsson och Mattsson 2018).

På ett sätt är det förståeligt om läraren $\mathrm{i}$ ett klassrum undviker att ta upp IsraelPalestinakonflikten. Samtidigt måste det som en del bedömare kallar "den nya antisemitismen" problematiseras och diskuteras. Personer som uttrycker antisemitiska idéer och stereotyper återfinns i många fall bland både kristna och muslimska grupper med rötter i Mellanöstern (Bunzl 2007: 2). I vissa fall har det gått så långt att man tvekar att delta i undervisning om judendom eller Förintelsen 
(Löwengart 2004: 24). Samma grupper med mellanösternbakgrund är i sin tur offer för fördomar och hat från främlingsfientliga och ultranationalistiska läger. Islamofobin har slagit rot som ett nytt europeiskt problem (Bunzl 2007: 4). I samtiden blir alltså både muslimer och judar utsatta för hat och fördomar, men av olika skäl och från olika håll. Matti Bunzl påpekar att här föreligger en paradox. Under början av nittonhundratalet skulle judarna uteslutas ur de europeiska nationalstaterna eftersom de inte ansågs höra hemma i en nationalstatsgemenskap (den så kallade "judefrågan”). $\mathrm{Nu}$ attackeras de av andra minoriteter eftersom de är väl integrerade i Europa (ibid. s. 27). Deborah Lipstadt påpekar också det motsägelsefulla i att judar, vilka allmänt uppfattas som privilegierade, samtidigt är offer för antisemitism (20 1 9: 94).

\section{Lärarstudenter om judendom}

Det är ovanligt att studenter har egna erfarenheter av judiskt liv och sed, om de inte själva tillhör ett judiskt sammanhang. För ett par decennier sedan hände det att studenter hade arbetat som au-pair i judiska familjer, främst i Storbritannien. Deras erfarenheter av att delta i ett judiskt hushåll berikade undervisningen, inte bara genom de personliga berättelserna, utan också genom att de kunde förmedla bilder av att judar är olika och har olika sätt att leva ut sin tradition på.

Vilka stereotyper och tankefigurer om judendomen har jag då mött hos lärarstudenter? En vanlig uppfattning bland studenter är att judendomen är en slags regelkristendom, men utan tron på Jesus. Istället för Jesus och Nya testamentet är det Gamla testamentet som man tror på och lever efter. Leif Carlsson formulerar detta betraktelsesätt som judendomen "som en prolog till kristendomen" (2013: 55, kursivering i originalet). Synsättet speglar tanken att det finns många likheter

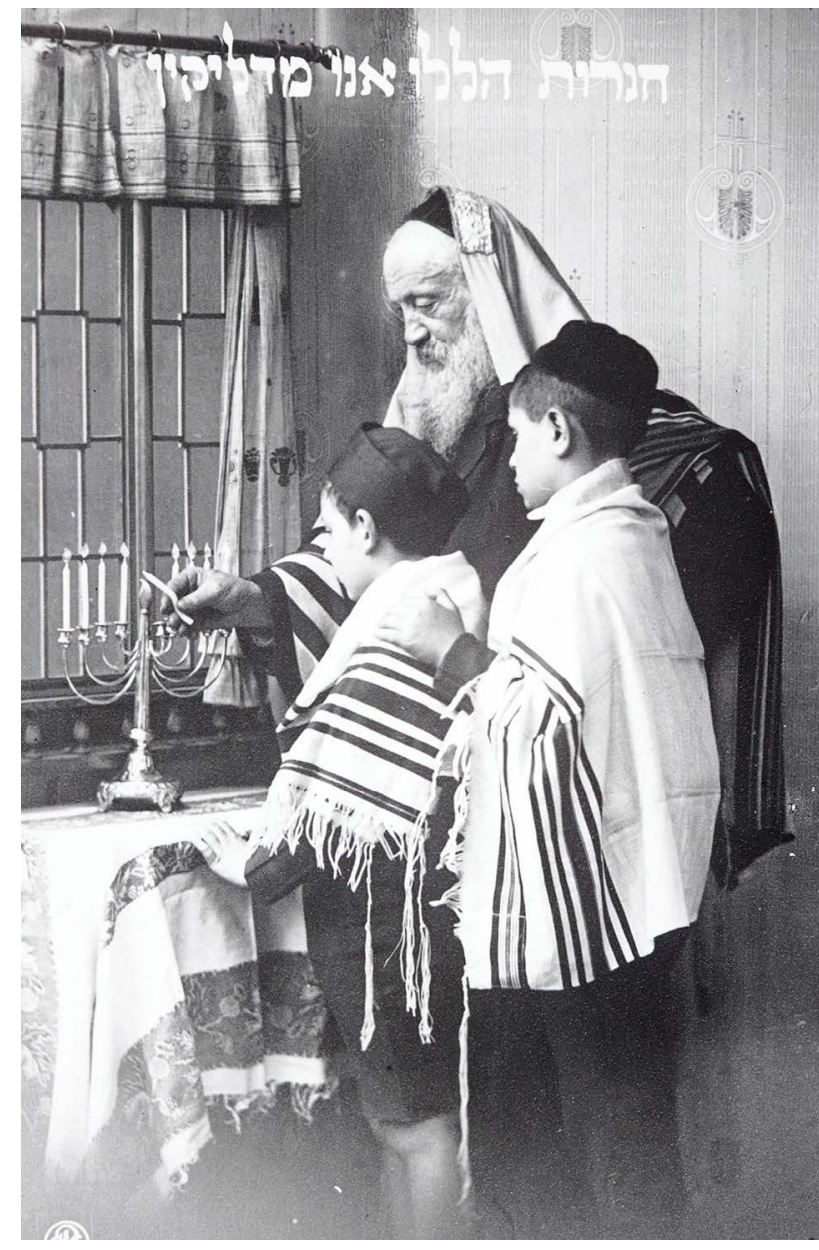

Tändning av chanukkaljusen. Undervisningsmaterial från Svenska Israelsmissionen. Svenska kyrkans arkiv, Uppsala.

mellan judendom och kristendom, men kristendomen är en utveckling, en förbättring. Judendomen har stannat upp och hållit fast vid Gamla testamentet.

Inte förvånande har många studenter svårt att förstå Talmuds relevans för judiskt liv och kultur. Tillgängligheten till Talmud, dess struktur och texter ligger på en mycket avancerad nivå, även för forskare. Därför är det inte konstigt att Talmud inte tas upp i skolläroböcker. Här är dock Amos $\mathrm{Oz}$ och Fania Oz-Salzbergers bok Jews and Words (2014) ett gott verktyg för att tillgodogöra sig 
Talmuds inflytande på sekulär judisk kultur. Boken diskuterar hur Talmuds värld kommer till uttryck i olika typer av judisk självförståelse genom tiderna, utan att vara för teknisk eller abstrakt.

\section{Utmaningarna med kosherslakt och omskärelse}

Högskolekursen för Samhällsorienterande ämnen för årskurserna $4^{-6}$ ger religionsämnet goda möjligheter att anknyta till utlevd religion. Med läroplanens skrivning att för årskurs 4 till 6 presentera "ritualer och religiöst motiverade levnadsregler, samt heliga platser och rum" (Lgr I I), erbjuder judendomen en rik och mångfacetterad tradition. Läroplanens fokus ger också läraren god möjlighet att anknyta till en av de senare forskningsinriktningarna, nämligen levd religion. Här förväntas läraren presentera hur religion levs och utförs i vardagen. En av judendomens centrala identitetsmarkörer är hur mat bereds, tillagas och äts. Som bekant kallas detta kosher (på hebreiska kasher eller kashruth).

Det är två huvudprinciper som ligger till grund för kosher. För det första: det ska vara en tillåten kategori av djur. Grunden för dessa finns i 3 Moseboken kapitel I I, respektive 4 Moseboken kapitel I4. Fågel och fisk är kosher, men definitionerna av vad som betraktas som fisk är skälet till att till exempel skaldjur inte är tillåtet (Unterman I 999: I 87I 89). Den andra principen gäller att man inte blandar kött och mjölkmat på grundval av 2 Moseboken 23:I 9 (även i 34:26 och 5 Mos. I 4:2 I). De djur som slaktas ska tömmas på sitt blod innan döden inträder. Denna typ av slakt kallas på svenska för skäktning (på hebreiska shechitah) och utförs av en utbildad och erfaren person.

Det är när jag föreläser om kosherslakt som diskussionen bland studenterna ofta börjar.
Synpunkterna gäller att skäktning är ett rått och grymt sätt att döda djur. Eftersom svensk lagstiftning föreskriver bedövning för ett djur som slaktas, är inte traditionell kosherslakt tillåten i Sverige (däremot i Danmark och i Tyskland). Studenternas reaktioner riktar sig. främst mot att döda djur genom att skära i dem och tappa dem på blod. Reaktionerna mildras i regel inte genom att jag framhåller att detta är en kontrollerad procedur där kniven är vass och att djuret sannolikt inte lider mer än vid ett industrialiserat slakteri. Inte heller parallellen till muslimsk halalslakt brukar ge en generösare förståelse. Kosherslakt är kontroversiellt.

Diskussionen om man ska äta djur är en annan och brukar dock kunna hållas isär från slakten. Jag har aldrig i sammanhanget mött åsikten att just denna sed visar att judar skulle vara ovanligt blodtörstiga. En sådan antisemitisk föreställning associeras inte första hand till slakten, utan kan snarare dyka upp i diskussioner om staten Israel.

Samma typ av reaktioner, det vill säga att man upplever att en judisk sed eller princip är grym, brukar också uttryckas i samband med undervisningen om omskärelsen av ett åtta dagar gammalt gossebarn. Liksom synpunkterna om kosherslakt handlar det främst om barnets rätt att värja sig mot vad en del studenter anser vara ett övergrepp. Traditionellt tillämpas heller inte bedövning vid omskärelsen och även detta kan uppröra. Den eventuella medicinska fördelen med omskärelsen ifrågasätts inte, utan det är barnets rätt att inte bli utsatt för vad man framhåller som ett oåterkalleligt ingrepp som man reagerar mot. Reaktionerna uppstår också när man förstår att även muslimer låter omskära yngre pojkar. En grundhållning hos många studenter, vilken man ofta motiverar med utgångspunkt i en aspekt i religionsfrihetensprincipen, är den att barnet ska ha rätt att välja själv och inte bli utsatt för religiöst tvång. $\AA$ andra sidan 
bör det då framhållas att samma princip ger judar rätt utöva de riter som är centrala för identiteten.

En tydlig tendens i sammanhanget är alltså avsaknaden av associationer till de äldre antisemitiska föreställningarna, vilket är positivt. Likaså är medvetenheten om intersektionella perspektiv och mänskliga rättigheter stark. Dock brister associationerna i relation till rätten att utöva sin religion enligt etablerade traditioner.

\section{Sabbatshissen}

Att undervisa om sabbaten utgör också en möjlighet att fånga judendomens rika traditioner. De flesta vet att sabbaten är en av judendomens viktigaste traditioner och att den firas på lördagen. De flesta känner också till att det finns handlingar som judar inte utför på sabbaten. Detta uppfattas dock av många som begränsande och som ett tvång. Sabbatens huvudsyfte till trots, nämligen att bereda vila för människan, ses den ibland som inskränkande på de val och friheter som en människa bör ha. När man undervisar om hur man kan leva under sabbaten med bekvämligheter och samtidigt vara trofast mot sabbatsprinciperna, behöver man ha tillräckligt med tid och en grupp som är villig att lyssna och förstå. Här finns risk för missförstånd och för att stereotyper befästs.

Principen att inte använda elektricitet på sabbaten begränsar ett modernt levnadssätt. Det finns dock teknik och sätt som kan göra ett vardagsliv möjligt under sabbaten. Till dessa hör sabbatshissen, vilken en del studenter har erfarenheter av. Sabbatshissen styrs alltså inte genom att man tycker på en knapp (en av principerna är att man inte slår på eller av elektrisk ström på sabbaten). Hissen stannar automatiskt på en våning $\mathrm{i}$ taget.

Reaktionerna på sabbatshissen brukar vara negativa. En sådan anordning upplevs vara omständlig eller "skenhelig". I förekommande fall uttryckas åsikten att praktiserande judar tror sig hålla buden, men de försöker kringgå dem. Att judar har respekt för sina traditioner och seder brukar de flesta acceptera, men att man kan anrätta teknik på ett modernt sätt upplevs alltså av en del som ett slags dubbelspel. Antingen håller man sabbaten konsekvent eller så gör man inte det. Som isolerad företeelse riskerar exemplet med sabbatshissen att förstärka negativa uppfattningar om judendomen. Undervisningens utmaning ligger $\mathrm{i}$ att presentera även svårförståeliga seder och bruk utan att ironisera eller exotisera. Har man inte understrukit respekten för sabbaten som något avgörande i en ortodox livsstil och dess anknytning till förbundstroheten, riskerar tankefiguren med judendomen som en lagreligion att ta över. Detta är uppenbar risk bland präststudenter.

\section{Staten Israel och Förintelsen}

Som påpekats ovan är frågor om staten Israel och den israelisk-palestinska konflikten ständigt aktuella. Eftersom det ofta inte finns tid att närmare gå in på bakgrunden till konflikten brukar jag nöja mig med att konstatera att själva den israelisk-palestinska konflikten i sin upprinnelse inte är religiös - alltså inte en konflikt mellan judendom och islam - utan handlar om rätten till land. Ett sådant konstaterande bortser visserligen från de senare årens ökade religiösa polarisering, inte minst kring heliga platser och en exklusiv judisk rätt till landet. Huvudsyftet med att relatera staten Israel till judendomen är dock att visa vilken avgörande roll Israel har haft för modern judisk identitet, inte minst när det gäller identitet, kultur och forskning.

Ett svårare didaktiskt avgörande gäller Förintelsen, vilken också de flesta studenter associerar till judendomen. Kännedom och kunskaper om både antisemitism och 
Förintelsen varierar mycket hos studenterna, vilket givetvis är ett viktigt skäl att belysa dessa ämnen. Av didaktiska skäl är det naturligtvis inte bra att sätta likhetstecken mellan judendomen och Förintelsen, speciellt inte som en ingång till judendomen. Man riskerar att presentera judendomen som ett evigt historiskt offer och dessutom indirekt genom nazismens lins, vilken drev tanken på judarna som framgångsrika och sammansvurna. Samma risk föreligger också i undervisning om islam, i det fall man inleder med att belysa religionen med islamofobins utgångspunkter.

\section{Religion som tro eller levnadsmönster?}

Som jag antytt finns det uppfattningar om vilken slags religionsutövning som är begriplig och acceptabel bland lärarstudenter. Många forskare påpekar att en sekulär, protestantisk syn på religion har slagit igenom som en slags mätare av vad som kan kännas igen som norm eller avvikelse vad avser utövning av religion. Det finns visserligen en motsättning mellan begreppen "sekulär" och "protestantisk", men i detta sammanhang ska man se sekulär som en följd eller en variation av modern protestantisk identitet. Jag vill formulera konsekvensen av en sekulär-protestantisk hållning som en skepsis mot religion som manifesterar sig i handlingar och livsmönster som kläder och mat.

I boken Det gudlösa folket (2015) uppmärksammar David Thurfjell just svårigheten för andra religiösa yttringar än den protestantiska att möta acceptans (20 15: 72-73). Han visar på protestantismens invävda roll i svenskt samhälle och utmanar den rådande bilden av svenskar som grundsekulariserade. Spåren av den luthersk-protestantiska traditionen lever dock kvar i det svenska samhället genom almanackans kristna högtider, bibliska namns popularitet vid namngivning och kyrkobyggnadernas givna plats i stad och på landsbygd.
Enligt Thurfjell betraktar de flesta svenskar sig inte som kristna, trots tillhörighet i Svenska kyrkan eller deltagande i kristna traditioner. Termen "kristen" vill man inte använda om sig själv. Som kristna betraktades "de andra", av mer väckelsekristen tillhörighet. Även Jenny Berglund drar liknande slutsatser utifrån framväxten av svensk religionsutbildning. När staten och skolan övertar den av kyrkan burna förväntan att skapa goda medborgare blir måttstocken för etik, livsåskådning och religion protestantisk-luthersk. På det här viset menar Berglund att det svenska samhället fortfarande kan betraktas som "ett samhälle marinerat i luthersk kristendom", samtidigt som man betraktar sig som religiöst neutral (Berglund 20I3:I8I). En konsekvens av detta blir att samtidigt som "svensken" betraktar sig som sekulär, betraktar man religiositet som utmärkande för samfund eller andra religioner som har en stark profilering eller vad man uppfattar som arkaiserande former av religion (Thurfjell 2015: I I I-I I 2). Den inre fromheten eller försanthållandet av Guds existens blir det mått som man mäter andra traditioner med (ibid. s. 229).

En sådan påstådd neutral hållning innebär alltså att många har svårt att förstå och rent av acceptera vikten av praktiska livsmönster som mat, kläder och handlingar relaterade till religiös identitet. Risken är att denna aspekt av religiös utlevelse ses i termer av antimodern fundamentalism och därmed som en fara för det sekulära samhället. Snarare är konkreta levnadsmönster en central identitetsmarkör främst i ortodox judendom, men naturligtvis är omskärelse av relevans också för liberal judendom. I judendomen uttrycks förhållandet med de halakiska frågorna på följande sätt: det är sättet att leva efter de bud och principer vars grund finns i de fem Moseböckerna, vilka är relaterade till och uttrycker förbundsidentiteten (Unterman r 999: 5, 8). Det är i sin tur de 
religiöst lärda, rabbinerna som definierar vad som är acceptabelt. Forskare drar också här paralleller till islams sharia där religiös praxis bestäms och förmedlas genom lärda auktoriteter (Peters 2005: 108-I09). Här delar alltså judendom och islam en utgångspunkt vilken ofta blir feltolkad. Tankefiguren "lagreligion" finns nära tillhands som en förklaring till hur just de religionerna skiljer sig från det övriga samhället.

\section{Judendom för präststudenter}

$\mathrm{Nu}$ följer några exempel på reaktioner inför judendom hos präststuderande i klassrummet. För präststudenter är judendom främst relaterad till Bibeln med dess två delar, alltså främst textrelaterad. Egna erfarenheter av "levd judendom" är ofta begränsade och därmed ökar risken för att man återger något av de äldre kristna förhållningssätten till judendom. Risken ökar också i den mån man framhåller de nytestamentliga texternas polemik mellan till exempel Jesus och fariséerna. Kunskap och kännedom om bibelns historia och tillkomsten av bibeltexter och kännedom om kristen undervisning skiljer som sagt präststudenter från lärarstudenter.

Som tankefigur var ersättningsteologi länge utgångspunkten för att från kristet håll beskriva överlägsenheten gentemot judendomen. Termen "ersättningsteologi", på engelska supersessionism, introducerades mot slutet av I 8oo-talet av prästen och forskaren Sydney Thelwall. Begreppet ersättningsteologi kom att beteckna föreställningen att kyrkan, det vill säga kristendomen, har ersatt judendomen som gudsfolk (Soulen 2008: 4I3-4I4). Det finns många tematiska variationer av tankefiguren, från föreställningen om judendomen som defekt, till den av att vara bestraffad på grund av att man inte accepterat Jesus som världens frälsare. Den sammanhållande idén är kristendomens överlägsenhet.
I regel inser präststudenter problemet med att konstruera judendomen som en sämre variant av kristendomen, eller som ett förstadium till kristendomen. Likaså förstår man det orättvisa i benämningen "Gamla testamentet”. De lämpligare termerna "Tanakh" och "den hebreiska Bibeln" har slagit igenom som beteckningar på den judiska Bibeln." Ändå finns behovet hos blivande präster att framhålla en avgörande skillnad mellan judendom och kristendom. Denna önskan omfattar allt från det historiska problemet varför judendom och kristendom blev två religiösa traditioner, till det homiletiska behovet att utlägga bibeltexter till kristendomens fördel.

För präststuderande innebär studiet av Nya testamentets texter ofta att man läser kurser om evangelierna för sig och Paulus brev för sig. En sådan indelning är ofta beroende av att texterna är innehållsligt olika och av olika svårighetsgrad. I regel läses kurser med evangelietexter före man läser texter från de paulinska breven. Det innebär att studenterna möter frågeställningar om Jesus och hans samtida judendom först.

\section{Jesus som jude}

Principen att Jesus var jude och att han levde och dog som jude bejakas av de flesta studenter. Tanken på Jesus judiskhet är heller ingen nyhet. Den har funnits med i forskningsdiskussionen sedan I 80o-talet. Jesus judiska identitet förstås primärt som ett historiskt faktum och studenter ser i regel inga problem

* "Den hebreiska Bibeln" har slagit igenom som beteckning vid Teologiska institutionen, Uppsala universitet. Den officiella benämningen för forskarämnet är "Gamla testamentets/ Hebreiska Bibelns exegetik" och man arbetar nära Forum för judiska studier. Se Teologiska institutionen 2020 . 
med att Jesus judiskhet skulle kollidera med en kristen förståelse av honom. Exegetiska läroböcker diskuterar olika judiska messiasföreställningar och olika tolkningar av begreppet "Guds son" vilket underlättar förståelsen av Jesus i judiska termer.

Det kan dock hända att principen "Jesus var jude" ändå fastnar i antitetiska tankefigurer, vilket Susannah Heschel (r998) uppmärksammar. Hon påpekar att sedan Abraham Geiger under slutet av i8oo-talet framhöll Jesus judiskhet har det funnits olika betoningar av "det judiska" hos Jesus, speciellt i den protestantiska diskussionen. Julius Wellhausen bejakade tanken på Jesus som jude, men Jesus var den siste sanne juden, eftersom han ansåg att det var fariséerna som korrumperat judendomen (Heschel r 998: 2 I 2). En sådan formulering är ovanlig idag, men däremot är problemet med Jesus relation till sin samtida judiska kontext en fråga som uppväcker antijudiska tankefigurer eller rent av stereotypa tolkningar.

Även om man anammat tanken på Jesus judiskhet finns varianten att tänka sig Jesus som hjälten som kämpar mot den judiska legalismen. Vid första påseendet kan de nytestamentliga texterna bekräfta en sådan uppfattning då Jesus eftertryckligt kritiserar fariséer och skriftlärda (Matteus 23 och Lukas I 8:9-14). Även om moderna forskare har problematiserat enkelspåriga läsningar här, försvarades detta antitetiska paradigm på olika sätt av erkända auktoriteter som Ethelbert Stauffer, Martin Dibelius och Joachim Jeremias (Klein I 978: 68-8 I). Även på svenskt håll fanns sådana tolkningar. En gemensam strävan hos dessa forskare var att hålla kvar bilden av Jesus som kämpen mot lagiskhet och ritualism, en hjälteroll som gjorde Jesus unik. Enligt en del av dessa forskare kostade detta honom livet (Jeremias I969: 267). På detta sätt bekräftade exegetisk forskning bilden av Jesus som gjorde upp med sin samtida judendom och fick betala för det, vilket utgör grunden för gudsmordsanklagelsen.

Denna bild av Jesus som den "kristne" hjälten som kämpar mot den "judiska" lagiskheten har jag inte träffat på i någon nämnvärd utsträckning bland dagens präststudenter. Däremot är tanken på att Jesus så att säga uppfinner vad man uppfattar som nya och epokgörande värden för kristendomen. De tydligaste exemplen rör kärlek och barmhärtighet mot de utstötta. Problemet är inte att man tillskriver Jesus dessa attribut, utan att man vill se honom som den ende juden under denna tid som vände sig till de utstötta (Levine 2006: I 2 I). Tanken att Jesus stod i samma tradition som Bibelns profeter anförs inte. Föreställningen om kontinuitet konkurrerar med tanken på att Jesus var unik.

Likaså kan kategorin "samhällets utstötta" vara mer av en homiletisk figur än en historisk rekonstruktion. Ett exempel på en sådan formulering ger Ragnar Leivestad i sin bok Hvem ville Jesus vare? (I982): "Alle fremstillinger av Jesu liv legger stor vekt på at Jesus hade omgang med mennesker som ikke var velkomne i det gode selskap, at han 'spiste sammen med tollere og syndere"” (s. I37). Amy-Jill Levine vänder sig mot en sådan generalisering och har kritiserat denna tillsammans med nio andra punkter där kristna kontrasterar Jesus mot sin judiska samtid. I detta fall med de utstötta, vänder hon på perspektivet och argumenterar för att det oftare handlar om individer som själva ställt sig utanför gemenskapen, tullindrivare med flera. Det är inte det religiösa ledarskapet som marginaliserat dem, enligt Levine. Samhället var - liksom det romerska - hierarkiskt och uppbyggt på segregation av olika klasser (Levine 20I I: 503). Man kan diskutera Levines historiska analys, men poängen ligger i att det ofta är homiletiska behov som styr en historisk förståelse av Jesus i hans 
samtida judendom. Ett sådant behov finns naturligt hos präststuderande.

Ämnet Jesus som jude inbjuder alltså till många olika infallsvinklar i undervisningen. Susannah Heschel sammanfattar utmaningen med Jesus som ett slags gångjärn mellan den judiska och kristna traditionen: Because Jesus was a Jew, Judaism cannot be fully denigrated, yet because Christians have broken with Judaism, it must be bad or inferior" (Heschel r 998: 239).

\section{Paulus och lagen}

Mitt sista exempel är präststudenters möten med Paulus och hans brev. I detta sammanhang framträder ett protestantiskt färgat tema: Paulus uppfattning av lagen. I andra avseenden kan präststudenters förförståelser av Paulus vara spridda. Det är vanligt att Paulus uppfattas som misogyn eftersom Paulus texter använts som argument mot prästvigning av kvinnor och kvinnligt ledarskap under I970- och 80-talen (Stenström 2013: 249-250). Samma förhållande gäller samkönad sexualitet. Vanligt är också att Paulus ofta uppfattas som tråkig och hans budskap som svårgenomträngligt (Åsberg 20I3: 295). Präststudenter vet i regel att Paulus texter innehåller centrala avsnitt om enheten i Kristus (Galaterbrevet 3:28), samt inte minst "rättfärdiggörelsen genom tron på Kristus" i Galaterbrevet 2:26 och Romarbrevet 3:28.

Tillbaka till frågan om Paulus och lagen. Frågan är komplex då tolkningen av Paulus brev i sig själv är krävande och präststuderande bär med sig den förenklande tankefiguren "lag och evangelium" från kyrklig undervisning. Denna konstruktion polariserar "lag" mot "evangelium". Som den moderna diskussionen länge har visat stämmer en sådan figur bättre på Martin Luther än på Paulus (Stendahl I960). Man kan heller inte dra

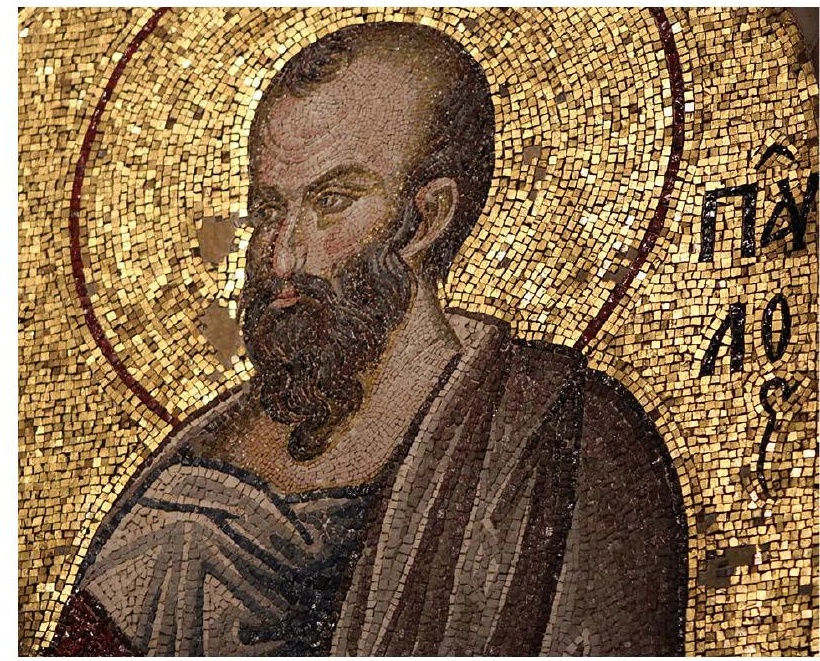

Paulus, mosaik från Chorakyrkan, Istanbul. Foto: Håkan Bengtsson.

raka linjer mellan Martin Luther och modern lutherdom. Här är det tillräckligt att konstatera att moderna studenters uppfattning av Luthers dikotomi mellan lag och evangelium förmedlats från kyrklig undervisning. Den är i sin tur beroende av äldre forskning och läroböcker. I svenskt sammanhang kan man inte bortse från påverkan av lundateologin med Anders Nygren i spetsen.

Även om Anders Nygrens berömda studie Den kristna kärlekstanken genom tiderna (I och II) inte direkt handlar om lag och evangelium, driver Nygren en dikotomisk tes om sann och falsk kärlek, eros eller agape. En av huvudpoängerna i hans idéhistoriska genomgång är att även inom kristendomen finns det en risk för ett etiskt och dogmatiskt självbedrägeri. I slutet av den andra delen formulerar han det som "kampen mot självkärleken" och "kampen mot tron på att göra gott" (Nygren i 936: 527, 534). Som lutheran ska man inte förlita sig på den egna förmågan att kunna bidra till sin egen rättfärdighet. Nygrens Paulustolkning kan sammanfattas med kontrasterandet av Paulus tidigare liv som förföljande farisé med Paulus liv sedan han mött Kristus på vägen till Damaskus. 
Paulus hade nått vägs ände: "Lagens väg för bort ifrån Gud... Efter att själv hava gått lagens väg till slut och ha sett att denna 'rättfärdighet' endast för bort från Gud, kunde Paulus ej längre upprätthålla sin gamla värdeordning" (ibid. s. 8 I). Många svenska systematiska teologer delade Nygrens slutsats och presenterade följaktligen Paulus uppfattning om lagen som en uppgörelse med ett annat trossystem än det protestantiskt kristna. Nygrens schema har följaktligen även försvårat en rättvis förståelse av romersk-katolsk etik (Bexell ı 99 г: 98).

\section{Lag eller evangelium}

De flesta kursplaner för präststuderande innehåller studiet av Galaterbrevet. Tillsammans med Romarbrevet spelade som bekant detta brev en central roll för uppkomsten av dikotomin "lag och evangelium". Inte sällan har både Galaterbrevet 2:I6 ("... människan inte blir rättfärdig genom laggärningar utan genom tron på Jesus Kristus ... ty av laggärningar blir ingen människa rättfärdig”) och Romarbrevet 3:28 uppfattats både som teologiska axiom och alltså höjdpunkter i breven (Bring I 958: 96; Bruce I982: 135). Anders Nygren skriver i sin kommentar till Romarbrevet: "Paulus har nedslagit lagrättfärdigheten och hävdat trosrättfärdigheten" (Nygren I 947: I74). Motsättningen mellan laggärningar och tro framställs som ett detroniserande av Torahn, i dessa sammanhang ensidigt kallat "lagen". Torahns betydelse i den judiska traditionen blir irrelevant och "lagen" blir en handlingsprincip som den kristne relaterar till som grund för sin fromhet. "Lagen" tecknas då som någonting bindande och betungande, medan evangeliet befriar och ger en kristen människa glädje och hopp. Lagens relevans har dessutom avskaffats för den kristne. Gustaf Aulén formulerar det på följande sätt: ”... lagens ställning blivit förvandlad genom Kristus" (citat Galaterbrevet 4:5 och Johannesevangeliet r: 17 ). "Lagen blir en fördärvsmakt, när den brukas som frälsningsväg..." (Aulén r 967: I I 7). Begreppet "lagen" definieras här närmast apologetiskt från en luthersk horisont.

Även om min beskrivning ovan är något skissartad, kan man hävda att den lutherska dikotomin "lag och evangelium", alternativt "lag och nåd" är en etablerad tankefigur där "lagen" står för judendomen och "evangeliet” för protestantisk kristendom (Stendahl I960: 450). Enkelheten i denna tudelning har appellerat till generationer av präster. Amy-Jill Levine har följdriktigt framhållit denna iakttagelse som ett exempel på vanliga kristna feltolkningar av judendomen (20 I I: 50I). Det är dock inte förvånande om präststuderande bär på en dikotomisk förståelse av temat Paulus och lagen.

Hur kan man bryta denna ensidiga förförståelse? Många studenter upplever de nyare Paulusperspektiven som både intressanta och relevanta. Med hermeneutiska insikter förstår man hur äldre tolkningsparadigm påverkat aktuell textförståelse. Likaså är diskussionen om olika översättningsmöjligheter av det grekiska uttrycket pistis christou (till exempel i Galaterbrevet 2:16, vanligtvis översatt "tron på Kristus") en nyckel till nya och alternativa tolkningar.

Även läroböcker i exegetik och i systematisk teologi speglar i regel en modern diskussionen om tro och gärningar. Redan på I 980talet refererade författarna Jarl Hemberg, Ragnar Holte och Anders Jeffner en sådan diskussion i läroboken Människan och Gud från r 982:"... förklarar Gud människan rättfärdig av ren nåd, inte i kraft av laggärningar, även om det förutsätts att denna nåd faktiskt yttrar sig i lydnad mot lagen" (Hemberg et al. I 982: 134). Här avspeglas både Krister Stendahls omtolkning av Paulus och den 
nyare Paulusforskningen. Boken återger även den centrala diskussionen om judars, respektive "hedningars" roll i Paulus texter om frälsning och rättfärdiggörelse. Detta är ett bra exempel på hur en lärobok återger forskningsinsikter.

\section{Sammanfattande utblickar}

För att sammanfatta utmaningen med att undervisa om judendom i svenska universitetssammanhang, handlar det å ena sidan om att vara korrekt $\mathrm{i}$ sin presentation av judisk tradition i nutid och i historia, å den andra om att vara medveten om vilka förförståelser som studenterna kan ha. Eftersom judendomen har sin identitet som en förbunds- och Torahcentrerad tradition är det viktigt att presentera livsstil, mat och identitetsmarkörer som relaterade till just förbundstanken. Handlingar och konkreta livsmönster är en central och naturlig del av religiös utlevelse. En lärare kan använda parallellerna med islam för att motverka föreställningen av religiös mathållning och klädsel som mekanisk eller legalistisk.

En annan viktig princip är att inte framställa skillnaderna mellan judendom och kristendom på ett antitetiskt sätt. Det gäller naturligtvis i både lärar- och prästutbildning. De skillnader som finns mellan judendom och kristendom har växt fram genom att man skapat olika traditioner och sedvänjor för att förstärka identitet och gruppkänsla. Det finns på det här sättet inget essentiellt med Jesus roll som kristendomens portalfigur, det vill säga att hans inträde i historien skulle skapat en ny religion. Jesus står idag snarare som en brygga mellan judendom och kristendom.

Som framgår i artikeln, har sekulariseringen på ett positivt sätt bidragit till att framställa judendomen som mindre exotisk, även om tankefiguren "lagreligion" fortfarande förekommer. Min analys erbjuder en tänkbar bakgrund till detta förhållande. En protestantisk religionsförståelse finns kvar i både skola och kristna samfund. Studenter i akademiska sammanhang relaterar dock inte längre till de grövsta antisemitiska stereotyperna. Ibland känner man inte ens till dem, vilket är en brist och på sikt en fara. Det som dock är utmärkande i undervisningen om Paulus är att präststudenter relaterar till den protestantiska tankefiguren av lagen som något negativt. Denna uppfattning har förstärkts genom en enkelspårig protestantisk tolkning av bibeltexter där en yttersta konsekvens kan bli att judendomen förstås som en religiös tradition utan modern relevans och utlevelse. Därför är det av stor vikt att både blivande lärare och präster lär sig betydelsen av religiösa traditioner som levda och relaterade till vardagen. Även präststuderande har god nytta av att förstå modern judendom.

Den ökade polariseringen i politik och media gör dock fortfarande judendomen till en måltavla för hat och fördomar. Det är naturligtvis omöjligt att förutsäga framtiden i detta avseende. Som lärare och pedagoger är det dock vår plikt att undvika att reproducera eller förstärka de problematiska tankefigurerna som hör hemma i historien.

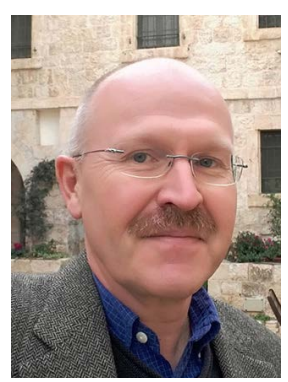

Håkan Bengtsson föddes i Göteborg 1962 och disputerade på en avhandling om bibeltolkning i Dödahavsrullarna. Han var chef för Svenska teologiska institutet i Jerusalem 2007-2014. Från 2015 har han arbetat som lektor i religionsvetenskap vid Uppsala universitet.

Nuvarande forskning behandlar judisk-kristna relationer och mission till judar i Wien och Israel i mitten av 1900-talet. 


\section{Litteraturreferenser}

Andersson, Lars M. 200o. En jude är en jude är en jude... Representationer av "juden" i svensk skämtpress omkring 1900-1930, avhandling (Lund: Nordic Academic Press).

Aulén, Gustaf. 1967. Kristen gudstro i förändringens värld (Stockholm: Skeab/Verbum).

Bengtsson, Håkan. 2006. 'Juden' som 'den andre' i svensk kyrklig exegetik", i Vara och värde, red. Lina Sjöberg och Lars Hartman, Uppsala Studies in Faiths and Ideologies I 7 (Uppsala universitet), I3I-I40.

Berglund, Jenny. 20I3."Swedish religion education: objective but marinated in Lutheran Protestantism?" Temenos 49(2): 165-I 84 .

-201 8."Religionsundervisning i det oförutsägbara klassrummet", i Interkulturell religionsdidaktik. Utmaningar och möjligheter, red. Olof Franck och Peder Thalén (Lund: Studentlitteratur), 275-29I.

Bexell, Göran. I 99r."Anders Nygren som etiker", i Anders Nygren som teolog och filosof. Rapport från symposiet vid 100-årsdagen av hans födelse, Religio 36 (Teologiska institutionen i Lund), 77-99.

Borgegård, Gunnel. r986. "Exempel på undervisning om judendomen i Sverige", Nordisk judaistik 7(I): 35-4I, doi: <https://doi. org/I0.30752/nj.69403>.

Bring, Ragnar. 1958. Tolkning av Nya testamentet VIII: Galaterbrevet (Stockholm: AB Verbum/ Kyrkliga Centralförlaget).

Bruce, F. F. 1982. The Epistle to the Galatians: A Commentary on the Greek Text (Milton Keynes: The Paternoster Press).

Bruchfeld, Stéphane. I 996. "Öga for öga, tand för tand". En granskning av svenska läromedel $i$ bistoria, religion och sambällskunskap for bögstadiet och gymnasiet om judendom, judisk bistoria och forintelsen (Stockholm: Svenska kommittén mot antisemitism).

Brumberg-Kraus, Jonathan D. I997."A Jewish ideological perspective on the study of Christian scripture", Jerwish Social Studies, 4(I): I 2 I - I 52 .

Bunzl, Matti. 2007. Anti-Semitism and Islamophobia: Hatreds Old and New in Europe (Chicago: Pricky Paradigm Press).

Byrne, Cathy. 201 4. Religion in Secular Education: What, in Heaven's name, are We Teaching our Children? International Studies in Religion and Society 2 I (Leiden: Brill).

Carlsson, Leif. 20 I 3. "Det forkastade judefolket".
Synen på judar och judendom i svenska skolläromedel (Lund: Sekel Bokförlag).

Fein, Helen. I987."Dimensions of antisemitism: attitudes, collective accusations and actions", i The Persisting Question: Sociological Perspectives and Social Contexts of Modern Antisemitism, red. Helen Fein, Current Research on Antisemitism I (Berlin: Walter de Gruyter), $67-85$.

Hartman, Sven G. 2000. "Hur religionsämnet formades", i Livstolkning och värdegrund. Att undervisa om religion, livsfrågor och etik, red. Edgar Almén, Ragnar Furenhed, Sven G. Hartman, Sven G. och Björn Skogar, Skapande vetande 37 (Linköpings universitet), 2 I $2-25 \mathrm{I}$.

-2008."Om skolans religionsundervisning, synen på eleven och de didaktiska frågorna - några reflektioner", Didaktikens forum 5 (3): $72-84$.

Hemberg, Jarl, Ragnar Holte, och Anders Jeffner. I 982. Människan och Gud. En kristen teologi (Stockholm: Liber förlag).

Heschel, Susannah. 1998. Abraham Geiger and the Jerwish Jesus (The University of Chicago Press).

Hinton, Perry R. 200o. Stereotyper, kognition och kultur (Lund: Studentlitteratur).

Illman, Karl-Johan. I 986."Judar och judendom i kristen skolundervisning", Nordisk judaistik 7(I): I-6, doi: <https://doi.org/10.30752/ nj.69399>.

Jeremias, Joachim. I 969. Jerusalem in the Time of Jesus (Minneapolis, MN: Fortress Press).

Kittelman Flensner, Karin. 201 5. Religious Education in Contemporary Pluralistic Sweden, avhandling (Göteborgs universitet), <https:// gupea.ub.gu.se/bitstream/2077/40808/I/ gupea_2077_40808_I.pdf> (läst I 3/5 2019).

Klein, Charlotte. 1978. Anti-Judaism in Christian Theology (Minneapolis, MN: Fortress Press).

Larsson, Göran, och Christer Mattson. 20 I 8. "Multinarrativ som pedagogisk metod - ett temanummer om läromedel", Religion och livsfrägor $\mathrm{I}: 4-5$.

Leivestad, Ragnar. I 982 . Hvem ville Jesus vare? (Oslo: Land og Kirke Gyldendal Norsk Forlag).

Levine, Amy-Jill. 2006. The Misunderstood Jew: The Church and the Scandal of the Jerwish Jesus (New York: HarperCollins).

—20I r. 'Bearing false witness: common errors made about early Judaism", i The Jerwish Annotated Nerw Testament: New Revised 
Standard Version, red. Amy-Jill Levine and Marc Zvi Brettler (Oxford University Press), $501-504$.

Lipstadt, Deborah E. 201 9. Antisemitism. Here and Now (New York: Schocken Books).

Löfstedt, Malin. 20 I 8. "Livsfrågor och etik i interkulturell religionsundervisning. För självreflektion och samreflektion", i Interkulturell religionsdidaktik. Utmaningar och möjligheter, red. Olof Franck och Peder Thalén (Lund: Studentlitteratur), 2 I7-234.

Löwengart, Mia. 2004. Bilden av antisemitismen och Förintelsen i svenska läromedel i historia. En undersökning av den kunskapssyn och de värderingar som förmedlas genom lärobokstexten (Uppsala universitet).

Martinson, Mattias. 201 7. Sekularism, populism, xenofobi. En essä om religionsdebatten (Malmö: Eskaton).

Nygren, Anders. 1936. Den kristna kärlekstanken genom tiderna. Eros och Agape (Uppsala: Svenska kyrkans diakonistyrelse).

— I 947. Tolkning av Nya testamentet VI: Romarbrevet (Stockholm: Svenska kyrkans diakonistyrelsens bokförlag).

$\mathrm{O} z$, Amos, och Fania Oz-Salzberger. 20 I 4. Jerws and Words (New Haven, CT: Yale University Press).

Peters, F. E. 2005. The Monotheists: Jerws, Christians, and Muslims in Conflict and Competition, 2: The Words And Will of God (Princeton, NJ: Princeton University Press).

Pickering, Michael. 200 I. Stereotyping: The Politics of Representation (London: Palgrave).

Soulen, R. Kendall. 2008."Supersession", i A Dictionary of Jewish-Christian relations, red. Edward Kessler och Neil Wenborn (Cambridge University Press), 4I 3-4I 4.

Stendahl, Krister. I96o."Paulus och samvetet", Svensk Exegetisk Arsbok 25: 62-77.

_ 1967. "Judaism and Christianity: a plea for a new relationship", Cross Currents I $7(4)$ : 445-458.

Stenström, Hanna. 2013. "Paulus och kvinnorna - tolkningar i I950-talets Sverige", i 2000 år med Paulus, red. Anders Ekenberg, Jonas Holmstrand och Mikael Winninge (Uppsala: Bibelakademiförlaget), 249-280.

Teologiska institutionen. 2020. Teologiska institutionen vid Uppsala universitet [webbsida], <https://www.teol.uu.se/ forskning/gamla-testamentets-exegetik/> (läst I $3 / 5$ 2019).

Thurfjell, David. 201 5. Det gudlösa folket. De postkristna svenskarna och religionen (Stockholm: Molin \& Sorgenfrei Akademiska).

Unterman, Alan. 1999. The Jerws: Their Religious Beliefs and Practices, 2 nd rev. edn (Eastbourne: Sussex Academic Press).

Vestøl, Jon Magne. 20 I 5."Att tala trovärdigt om religion i klassrummet. Några religionsdidaktiska utmaningar", Religion och livsfrågor 3: 8-io.

Willander, Erika. 2or 9. Sveriges religiös landskap - sambörighet, tillhörighet och mångfald under 2000-talet, SST:s skriftserie 8 (Bromma: Myndigheten för stöd till trossamfund).

Åsberg, Christer. 20 I 3. "Paulus i svensk kultur", i 2000 år med Paulus, red. Anders Ekenberg, Jonas Holmstrand och Mikael Winninge (Uppsala: Bibelakademiförlaget), 28 I-304. 